University of Wollongong

Research Online

Faculty of Engineering and Information

Faculty of Engineering and Information

Sciences - Papers: Part A

Sciences

$1-1-2013$

\title{
Removal of trace organic contaminants by an MBR comprising a mixed culture of bacteria and white-rot fungi
}

Luong N. Nguyen

University of Wollongong, Inn909@uowmail.edu.au

Faisal I. Hai

University of Wollongong, faisal@uow.edu.au

Shufan Yang

University of Wollongong, sy527@uowmail.edu.au

Jinguo Kang

University of Wollongong, jkang@uow.edu.au

Frederic D L Leusch

Griffith University

See next page for additional authors

Follow this and additional works at: https://ro.uow.edu.au/eispapers

Part of the Engineering Commons, and the Science and Technology Studies Commons

Research Online is the open access institutional repository for the University of Wollongong. For further information contact the UOW Library: research-pubs@uow.edu.au 


\title{
Removal of trace organic contaminants by an MBR comprising a mixed culture of bacteria and white-rot fungi
}

\begin{abstract}
The degradation of 30 trace organic contaminants (TrOC) by a white-rot fungus-augmented membrane bioreactor (MBR) was investigated. The results show that white-rot fungal enzyme (laccase), coupled with a redox mediator (1-hydroxy benzotriazole, HBT), could degrade TrOC that are resistant to bacterial degradation (e.g. diclofenac, triclosan, naproxen and atrazine) but achieved low removal of compounds (e.g. ibuprofen, gemfibrozil and amitriptyline) that are well removed by conventional activated sludge treatment. Overall, the fungus-augmented MBR showed better TrOC removal compared to a system containing conventional activated sludge. The major role of biodegradation in removal by the MBR was noted. Continuous mediator dosing to MBR may potentially enhance its performance, although not as effectively as for mediator-enhanced batch laccase systems. A ToxScreen3 assay revealed no significant increase in the toxicity of the effluent during MBR treatment of the synthetic wastewater comprising TrOC, confirming that no toxic by-products were produced. 2013 Elsevier Ltd.
\end{abstract}

\section{Keywords}

removal, rot, fungi, bacteria, culture, mixed, comprising, mbr, contaminants, organic, trace, white

\section{Disciplines}

Engineering | Science and Technology Studies

\section{Publication Details}

Nguyen, L. N., Hai, F. I., Yang, S., Kang, J., Leusch, F. D L., Roddick, F., Price, W. E. \& Nghiem, L. D. (2013). Removal of trace organic contaminants by an MBR comprising a mixed culture of bacteria and white-rot fungi. Bioresource Technology, 148 (November), 234-241.

\section{Authors}

Luong N. Nguyen, Faisal I. Hai, Shufan Yang, Jinguo Kang, Frederic D L Leusch, Felicity Roddick, William E. Price, and Long D. Nghiem 


\section{Removal of trace organic contaminants by an MBR comprising a mixed culture of bacteria and white-rot fungi}

\section{Bioresource Technology 148 (2013) 234-241}

Luong N. Nguyen ${ }^{\text {a }}$, Faisal I. Hai ${ }^{a^{*}}$, Shufan Yang ${ }^{\text {a }}$, Jinguo Kang ${ }^{\text {b }}$, Frederic D. L. Leusch ${ }^{\text {, }}$ Felicity Roddick ${ }^{\mathrm{d}}$, William E. Price ${ }^{\mathrm{b}}$, and Long D. Nghiem ${ }^{\mathrm{a}}$

${ }^{\text {a }}$ Strategic Water Infrastructure Laboratory, School of Civil, Mining and Environmental Engineering, University of Wollongong, Wollongong, NSW 2522, Australia

${ }^{b}$ Strategic Water Infrastructure Laboratory, School of Chemistry, University of Wollongong, Wollongong, NSW 2522, Australia

${ }^{\mathrm{c}}$ Smart Water Research Centre, School of Environment, Griffith University, Southport, QLD 4222, Australia

${ }^{\mathrm{d}}$ School of Civil, Environmental and Chemical Engineering, RMIT University, Melbourne, Victoria 3001, Australia

* Corresponding author: Faisal I. Hai, Email: faisal@uow.edu.au; Ph: +61 242213054 


\section{Research Highlights:}

- Fungal enzyme could degrade TrOC that are resistant to bacterial degradation

- Some TrOC well removed by bacteria were poorly removed by fungal enzyme

- Bacterial well complemented the degradation of TrOC by a fungal MBR

- Biodegradation was a major TrOC removal mechanism by MBR

- Redox-mediator dosing improved removal of resistant TrOC diclofenac by MBR 


\section{Abstract:}

The degradation of 30 trace organic contaminants (TrOC) by a white-rot fungus-augmented membrane bioreactor (MBR) was investigated. The results show that white-rot fungal enzyme (laccase), coupled with a redox mediator (1-hydroxy benzotriazol, HBT), could degrade TrOC that are resistant to bacterial degradation (e.g. diclofenac, triclosan, naproxen and atrazine) but achieved low removal of compounds (e.g. ibuprofen, gemifibrozil and amitriptyline) that are well removed by conventional activated sludge treatment. Overall, the fungus-augmented MBR showed better TrOC removal compared to a system containing conventional activated sludge. The major role of biodegradation in removal by the MBR was noted. Continuous mediator dosing to MBR may potentially enhance its performance, although not as effectively as for mediator-enhanced batch laccase systems. A ToxScreen3 assay revealed no significant increase in the toxicity of the effluent during MBR treatment of the synthetic wastewater comprising TrOC, confirming that no toxic by-products were produced.

Keywords: white-rot fungi; membrane bioreactor; trace organic contaminants (TrOC); mediatorenhanced laccase system; biosorption and biodegradation

\section{List of abbreviation and nomenclature:}

CAS: Conventional activated sludge

CFU: Colony forming unit

DMP: 2,6-dimethoxy phenol

EMR: Enzymatic membrane reactor

EDG: Electron donating functional groups 
EWG: Electron withdrawing functional groups

HBT: 1-hydroxy benzotriazole

HRT: Hydraulic retention time

LiP: Lignin peroxidase

MnP: Manganese peroxidase

MEB: Malt extract broth

MBR: Membrane bioreactor

MLSS: Mixed liquor suspended solids

MLVSS: mixed liquor volatile suspended solids

PhACs: Pharmaceutically active compounds

TOC: Total organic carbon

TN: Total nitrogen

TMP: Transmembrane pressure

TrOC: Trace organic contaminants

$\log$ D: logarithm of the distribution coefficient which is the ratio of the sum of concentrations of all forms of the compound (ionised and unionised) in octanol and water at a given $\mathrm{pH}$. 


\section{Introduction}

Trace organic contaminants (TrOC) comprise a wide range of naturally occurring and synthetic compounds including pharmaceutically active compounds (PhACs), steroid hormones, pesticides and industrial chemicals. TrOC have been detected in raw sewage, secondary treated effluents, surface water bodies, and even in drinking water (Snyder, 2008). Given the potential adverse effects of TrOC on aquatic organisms and human health, recent studies have been devoted to improving current processes or developing new technologies for the removal of these compounds from wastewater (Boonyaroj et al., 2012; Navaratna et al., 2012; Tadkaew et al., 2011). The conventional activated sludge (CAS) treatment process (that is widely employed for wastewater treatment) can effectively remove bulk organic matter and nutrients (nitrogen and phosphorus). However, the CAS process was not specifically designed to remove TrOC. Thus, the removal efficiency of TrOC by CAS can vary significantly (Hai et al., 2013). Due to the limitations of TrOC removal by the bacteria-dominated CAS process, several small-scale batch studies have been conducted to explore the application of white-rot fungal bioremediation (Yang et al., 2013b). White-rot fungi possess one or more extracellular enzymes including lignin peroxidases (LiP), manganese-dependent peroxidases $(\mathrm{MnP})$ and laccases. They can efficiently degrade a wide range of persistent organic compounds including TrOC that are resistant to bacterial degradation (Marco-Urrea et al., 2009; Tran et al., 2010; Yang et al., 2013b).

Despite the significant number of small-scale sterile batch test studies, only a few studies have been conducted on continuous flow fungal reactors (Blánquez \& Guieysse, 2008; Jelic et al., 2012; Rodarte-Morales et al., 2012). Furthermore, to date, only two studies have investigated the removal of TrOC under non-sterile conditions, which are more realistic for a practical 
application (Yang et al., 2013a; Zhang \& Geißen, 2012). Compared to the performance in pure culture batch tests, that of a continuous flow fungal reactor can be adversely affected due to two major phenomena: i) continuous washout of fungal extracellular enzyme with treated effluent (Hai et al., 2012b; Yang et al., 2013a), and ii) bacterial destabilization of fungal activity (Hai et al., 2009; Libra et al., 2003). On the other hand, combination of white-rot fungi with activated sludge may bring about synergistic degradation of TrOC. For example, based on a series of batch tests, Hai et al. (2012a) reported enhanced removal of three widely used resistant pesticides from their mixed solution by implementing a mixed culture of bacteria and white-rot fungus. However, a systematic assessment of the relative performance of fungus and activated sludge, and the implications of combining them in a continuous flow system is absent from the literature.

Fungal enzyme-catalysis can be enhanced by adding low molecular weight mediators that act as an 'electron shuttle' between the oxidizing enzyme and target compounds (Kim \& Nicell, 2006). The degree of enhancement depends predominantly on the type of mediator and the TrOC structure. Apart from a few short-term studies on enzymatic membrane reactors (EMR) (e.g. Lloret et al. (2012)), most of the studies on mediator-enhanced enzyme system have been carried out in batch mode. Even with the EMR configuration, gradual loss of enzymatic activity due to various physical, chemical and biological inhibitors under wastewater conditions is inevitable. Thus, it is necessary to periodically replenish the reactor with fresh enzyme. By contrast, a whole-cell reactor may bring about the added advantage of continuous enzyme production. In this context, continuous dosing of a mediator to a whole-cell reactor may achieve enhanced removal of TrOC. However, no work in this line could be identified in the literature.

This study aims to evaluate the removal of TrOC by a reactor containing the white-rot fungus Trametes versicolor (ATCC 7731) and activated sludge. To prevent the washout of the fungus 
(Hai et al., 2012b), a microfiltration membrane was coupled with the mixed culture bioreactor. A control activated sludge reactor was also operated to assess the implications of the combination explored. To further facilitate the comparison between fungus and activated sludge, the TrOC degradation capacity of the fungal enzyme (laccase) was assessed in a series of batch tests. The effect of continuous dosing of a mediator (1- hydroxy benzotriazole, HBT) to the fungusaugmented MBR on TrOC removal was also studied.

\section{Materials and methods}

Two identical MBR systems, one with activated sludge and the other inoculated with fungusaugmented sludge (details follow in Section 2.4), were operated under similar conditions to enable assessment of the effect of white-rot fungus (T. versicolor) augmentation with conventional activated sludge. Because of the practical difficulties in maintaining sterility (Libra et al., 2003), operation of a control MBR with a pure culture of $T$. versicolor was not attempted. However, in order to shed light on the probable differences between the performances of the mixed culture and the pure fungus culture, the results of the batch (fungal) enzymatic tests (Section 2.3) were taken into account.

\subsection{Trace organic contaminants}

A set of 30 TrOC was selected for investigation in this study based on their widespread occurrence in raw sewage and sewage-impacted water bodies and their diverse physicochemical properties (e.g. hydrophobicity and molecular weight) as presented in Supplementary Data Table 1. These compounds represent six major groups of TrOC including eleven PhACs, five steroid hormones, six pesticides, three industrial chemicals, three UV filters and two phytoestrogens. A stock solution of all selected TrOC was prepared in pure methanol at a concentration of $25 \mathrm{mg} / \mathrm{L}$ (each $\mathrm{TrOC}$ ) on a monthly basis and stored at $-18{ }^{\circ} \mathrm{C}$ prior to use with dilution. 


\subsection{White-rot fungi, growth medium, synthetic wastewater and mediator}

The white-rot fungus T. versicolor ATCC 7731 (USA) was used in this study. The fungus was maintained on malt extract agar (Oxoid, England). A liquid culture was obtained by inoculating pieces of fungus grown on agar into malt extract broth (5 g/L) (MEB) (Merck, Germany). Refrigerated stock fungal suspension was poured into sterilised growth medium (pH 4.5) and incubated in a temperature-controlled $\left(28^{\circ} \mathrm{C}\right)$ shaker for $7 \mathrm{~d}$ in order to obtain fresh batches of fungus. The supernatant of the same fungal culture was harvested as crude enzyme extract and refrigerated $\left(4{ }^{\circ} \mathrm{C}\right)$ in sterilized bottles.

A malt-based synthetic wastewater consisting of MEB (0.5 g/L), $\mathrm{KH}_{2} \mathrm{PO}_{4}(0.2 \mathrm{~g} / \mathrm{L}), \mathrm{MgSO}_{4}$ $(0.05 \mathrm{~g} / \mathrm{L}), \mathrm{FeSO}_{4}(0.01 \mathrm{~g} / \mathrm{L})$ and thiamine $(0.001 \mathrm{~g} / \mathrm{L})$ (Yang et al., 2013a) was used for the operation of the fungus-augmented MBR as described in Section 2.4. All chemicals used for preparing the synthetic wastewater were dissolved in Milli-Q water. The $\mathrm{pH}$ of the synthetic wastewater was adjusted to 4.5 with $\mathrm{HCl}(4 \mathrm{M})$. The MBR containing activated sludge (see Section 2.4), on the other hand, was fed with a synthetic wastewater validated previously for activated sludge (Nguyen et al., 2012). The stock TrOC solution (Section 2.1) was introduced to the respective synthetic wastewater to obtain a concentration of approximately $5 \mu \mathrm{g} / \mathrm{L}$ of each TrOC and then fed continuously to the MBRs.

HBT (Sigma-Aldrich, Australia), a widely studied redox mediator for fungal laccase (Coniglio et al., 2008; Hata et al., 2010), was used in this study. A stock solution of the mediator was prepared at a concentration of $50 \mathrm{mM}$ and stored at $4{ }^{\circ} \mathrm{C}$.

\subsection{Protocol of batch enzymatic degradation tests}


A series of batch enzymatic degradation tests was conducted in triplicate with a crude extracellular extract harvested from fungal culture (henceforth referred to as 'enzyme solution') (Section 2.2). The stock TrOC solution was added to the enzyme solution $(25 \mathrm{~mL})$ to achieve an initial concentration of $100 \mu \mathrm{g} / \mathrm{L}$ of each compound. Additional containers were incubated to assess the effect of addition of the redox mediator HBT at a concentration of $1 \mathrm{mM}$. Control samples comprised TrOC in Milli-Q water. All the containers were covered with aluminium foil and incubated in a rotary shaker at $70 \mathrm{rpm}$ and $28{ }^{\circ} \mathrm{C}$ for $24 \mathrm{~h}$. The initial laccase activity of the enzyme solution was $35 \mu \mathrm{M}$ substrate /min (See Section 2.5.2). Laccase activity was also measured at the end of the experiment to assess any drop in enzymatic activity. At the end of the incubation period, the whole test solution was harvested as GC-MS sample (Section 2.5.1). The samples were diluted to $500 \mathrm{~mL}$ with Milli-Q water and filtered through $0.45 \mu \mathrm{m}$ glass fibre filters (Filtech, Australia). The $\mathrm{pH}$ of the sample was adjusted to 2.5 by using $\mathrm{H}_{2} \mathrm{SO}_{4}(4 \mathrm{M})$ and the sample was subjected to solid-phase extraction (SPE) prior to GC-MS analysis.

\subsection{MBR systems and operating protocol}

As noted earlier, two identical MBR systems, one inoculated with fungus-augmented sludge (details follow) and the other with activated sludge, were operated under similar conditions. Each MBR comprised of a 5.5 L (active volume) glass reactor and housed a PVDF hollow fiber membrane module (SADF0790M mini module, Mitsubishi Rayon Engineering, Japan) with a nominal pore size of $0.4 \mu \mathrm{m}$ and a total effective membrane surface area of $0.074 \mathrm{~m}^{2}$. The membrane was operated on a 8 min "suction" and 2 min "relaxation" cycle under an average flux of $1.54 \mathrm{~L} / \mathrm{m}^{2} \mathrm{~h}$, resulting in a hydraulic retention time (HRT) of $2 \mathrm{~d}$. A vacuum gauge (Model 840064, Sper Scientific Ltd., USA), which was connected to a data logging computer, was used to monitor transmembrane pressure (TMP) as an indicator of membrane fouling. Aeration pumps 
(ACO-002, Zhenjiang Sensen Industry Co. Ltd, China) supplied air to the reactor through diffusers. Peristaltic pumps (Master-Flex, Cole-Parmer, Australia) were used to supply influent and draw effluent. The MBRs were placed in a water bath to maintain the mixed liquor temperature at $28.0 \pm 0.2{ }^{\circ} \mathrm{C}$ by a heating immersion circulator (Julabo, Germany). The dissolved oxygen (DO) concentration in the reactors was monitored daily by a DO meter (YSI, USA). Aeration was provided to avoid settling of the mixed liquor in the corners of the reactor, leading to a consistently high DO concentration of approximately $5 \mathrm{mg} / \mathrm{L}$ within the MBRs.

The fungus-augmented MBR in the current study was seeded with sludge from a previous labscale MBR (Yang et al., 2013a) which was originally inoculated with a pure culture of $T$. versicolor (ATCC 7731) and operated for $90 \mathrm{~d}$ to treat a synthetic wastewater containing two model TrOC (bisphenol A and diclofenac). Because the original MBR (Yang et al., 2013a) was operated under non-sterile conditions, a mixed culture of fungi and bacteria gradually developed in the reactor. The mixed sludge, however, continued to exhibit laccase (a white-rot fungal enzyme) activity - a characteristic uncommon to activated sludge. After seeding with this fungus-augmented sludge, the MBR in the current study was operated for $110 \mathrm{~d}$, of which the investigation over the last $30 \mathrm{~d}$ was conducted with continuous dosing of $5 \mu \mathrm{M}$ of HBT (redox mediator) to the MBR. The conventional MBR, on the other hand, was inoculated with activated sludge from another lab-scale MBR operated for over 3 years for TrOC removal (Tadkaew et al., 2011). The initial mixed liquor suspended solid concentration in both the MBRs was $3 \mathrm{~g} / \mathrm{L}$. Sludge was withdrawn from the MBRs only during sampling. As noted earlier, the MBRs were fed continuously with respective synthetic wastewater (Section 2.2) spiked with the selected 30 TrOC each with a concentration of approximately $5 \mu \mathrm{g} / \mathrm{L}$.

\subsection{Analytical methods}




\subsubsection{Basic parameters and trace organic contaminants}

Total organic carbon (TOC) and total nitrogen (TN) concentrations were measured simultaneously by a Shimadzu TOC/TN- $\mathrm{V}_{\mathrm{CSH}}$ analyser (Japan). The determination of mixed liquor suspended solid (MLSS) and mixed liquor volatile suspended solid (MLVSS) concentration (Method 2540E) and enumeration (colony forming unit, $\mathrm{CFU} / \mathrm{mL}$ ) of fungi (Method 9610 C) and bacteria (Method 9215) followed Standard Methods for the Examination of Water and Wastewater (Eaton et al., 2005).

The TrOC concentrations in the batch test samples and MBR feed and permeate samples were measured by a previously reported analytical technique involving SPE, derivatisation and quantitative determination by a Shimadzu GC/MS (QP5000) system (Hai et al., 2011). The GC/MS system was equipped with a Shimadzu AOC 20i autosampler and a Phenomenex Zebron ZB-5 (5\% diphenyl-95\% dimethyl polysiloxane) capillary column ( $30 \mathrm{~m}$ x $0.25 \mathrm{~mm}$ ID, $\mathrm{d}_{\mathrm{f}}=0.25$ $\mu \mathrm{m})$ was used. The quantitative detection limits of this analytical method were compound specific and in the range from 1 to $20 \mathrm{ng} / \mathrm{L}$. The aqueous phase TrOC removal efficiency was calculated by comparing the influent and permeate concentrations (MBR) and initial and final concentrations with corrections applied according to the control sample (batch tests).

TrOC adsorbed on the MBR biomass was extracted by a previously developed solvent extraction method (Wijekoon et al., 2013). Freeze-dried ( $0.5 \mathrm{~g})$ sludge was ground to powder and subjected to repeated solvent extraction (methanol and dichloromethane) via sonication. The extracted TrOC in the solution was diluted to $500 \mathrm{~mL}$ with Milli-Q water. Then, the samples were subjected to SPE and finally to GC-MS analysis as outlined above. The concentration was expressed as ng TrOC per g of MLSS (dry wt). 


\subsubsection{Laccase activity assay}

Extracellular laccase activity assay comprised of monitoring the change in absorbance at $468 \mathrm{~nm}$ due to the oxidation of $10 \mathrm{mM}$ 2,6-dimethoxy phenol (DMP) by laccase in $100 \mathrm{mM}$ sodium citrate buffer solution ( $\mathrm{pH} 4.5$ ) at room temperature over 2 min using a spectrophotometer (UVVisible UV-1700, Shimadzu, Kyoto, Japan). Laccase activity was then calculated from the molar extinction coefficient $\varepsilon=49.6 / \mathrm{mM} / \mathrm{cm}$ and expressed in $\mu \mathrm{M}$ substrate (DMP) $/ \mathrm{min}$. Mycelium bound laccase activity of the MBR biomass was determined as per the method described by Yang et al. (2013a) and presented as $\mu \mathrm{M}$ (DMP) / $\mathrm{min} / \mathrm{g}$ MLSS.

\subsubsection{ToxScreen 3 assay}

MBR feed and permeate samples were tested in duplicate for bacterial toxicity by measuring bioluminescence inhibition in Photobacterium leiognathi as described previously (CheckLight, 2010; Ulitzur et al., 2002). In brief, lyophilised bacteria were rehydrated in hydration buffer and incubated at $4{ }^{\circ} \mathrm{C}$ for $24 \mathrm{~h}$ prior to use. A 6-point 2 -fold serial dilution of each sample was created in pro-organic buffer, mixed with an equal volume of assay buffer and incubated for 5 min at $30^{\circ} \mathrm{C}$, and then incubated with the rehydrated bacteria for $15 \mathrm{~min}$ at $30^{\circ} \mathrm{C}$. Each toxicity test included negative (assay blank) and positive controls (sodium chloroacetate). At the end of the incubation, bioluminescence was measured as relative light units (RLU) at $490 \mathrm{~nm}$ using a LB9509 Berthold Junior Portable Luminometer (Berthold Technologies, Germany) and the percent inhibition was calculated as $100-\left(\left(\operatorname{RLU}_{\text {sample }} / \mathrm{RLU}_{\text {negative_control }}\right) \times 100\right)$. Percent inhibition was plotted against sample concentration for each replicate sample and the $\mathrm{IC}_{20}$ was calculated from a linear fit of the data in the linear response range (i.e., up to $\mathrm{IC}_{40}$ ). The relative toxic unit of each sample (rTU) was then calculated as $1 / \mathrm{IC}_{20}$. 


\section{Results and discussion}

\subsection{Batch enzymatic degradation tests}

\subsubsection{Effect of TrOC structure}

Figure 1 depicts the removal of 30 TrOC by the crude enzyme extract (laccase) with and without addition of a mediator (1-hydroxy benzotriazole). Of the 30 TrOC investigated in this study, significant enzymatic degradation of 13 was observed. The remaining TrOC showed low or negligible enzymatic degradation. This is consistent with previous work for the removal of carbamazepine, ibuprofen, clofibric acid, ketoprofen and atrazine which have been studied before (Hata et al., 2010; Mougin et al., 1997; Tran et al., 2010).

The variation in the enzymatic degradation efficiency of the 30 selected TrOC investigated here can be attributed to their chemical structures. It is well known that laccase promotes the single electron oxidation of phenols (Yang et al., 2013b). Accordingly, we observed high removal (70 90\%, Figure 1) of the majority of the TrOC possessing phenolic moiety (i.e. hydroxyl functional group attached to a benzene ring). This group of compounds includes steroid hormones (17- $\alpha$ ethinylestradiol, 17- $\beta$-estradiol, 17- $\beta$-estradiol-17-acetate, estrone and estriol) and some industrial chemicals (bisphenol A, 4-tert-butyphenol and 4-tert-octyphenol). Our observation is consistent with the high reported degradation of phenolic TrOC such as bisphenol A, nonylphenol, estrone, and 17- $\alpha$-ethinylestradiol (Cajthaml et al., 2009; Lloret et al., 2012).

The low or negligible removal of some TrOC can be explained based on the concept of impact of electron withdrawing functional groups (EWG) and electron donating functional groups (EDG) within the TrOC structure on their oxidative degradation. Conducting an investigation with a set of 40 TrOC, Tadkaew et al. (2011) observed that EWG render TrOC less susceptible to oxidative catabolism. Chivakula and Renganathan (1995) reported that, among the dyes tested, only those 
containing EDG (e.g. methyl or methoxy substituent) were oxidized by laccase. In our study, the low/negligible removal of the chlorinated compounds such as clofibric acid, fenoprop, pentachlorophenol and atrazine (Figure 1) can be explained by the fact that the chloride group is a strong EWG. Treatment by laccase from T.versicolor was previously reported to inefficiently degrade clofibric acid (Tran et al., 2010). The negligible removal of ametryn in our study is in line with the report of Mougin et al. (1997) that the degradation of triazine pesticides can be initiated via $\mathrm{N}$-dealkylation, but they are usually resistant to bacterial as well as fungal degradation.. Poor removal of metronidazole, propoxur and carbamazepine in our study can be attributed to the presence of strong EWG (i.e. nitro, carbamate and amide, respectively) in their structures. Notably, similar to the results presented here, Tran et al. (2010) also reported poor degradation of carbamazepine by a crude laccase solution.

\section{[FIGURE 1]}

\subsubsection{Mediator-enhanced enzymatic degradation}

Of the $18 \mathrm{TrOC}$ that registered negligible degradation by only laccase (Figure 1), the addition of HBT significantly improved (22\% - 93\% improvement) the removal of eight of them, namely, gemfibrozil, amitriptyline, ametryn, primidone, salicylic acid, enterolactone, atrazine and oxybenzone. HBT addition also improved the removal of pentachlorophenol (31\% to $91 \%$ ), diclofenac (70\% to $95 \%$ ), and naproxen (20\% to $98 \%$ ). The oxidation of even some phenolic substrates by laccase can be low as steric factors may hinder their approach to the active site of the enzyme (D'Acunzo et al., 2006). The small aminoxyl radical species generated from HBT by laccase can abstract $\mathrm{H}$-atom from the $\mathrm{O}-\mathrm{H}$ bond of these substrates and can form the corresponding phenoxyl radical, which in turn reacts with the substrate (Coniglio et al., 2008). This mechanism may explain the significantly improved degradation of the phenolic TrOC such 
as salicylic acid, pentachlorophenol, enterolactone and oxybenzone in the presence of HBT in our study (Figure 1). Furthermore, the laccase-HBT system can cover the degradation of a broader spectrum of compounds as the oxidised form of HBT has redox potential of the order of $1.0-1.1 \mathrm{~V}$, which is higher than that of laccase only (0.17V) (D'Acunzo et al., 2006). This can explain the better removal of some of the non-phenolic TrOC (i.e. gemfibrozil, amitriptyline, ametryn, primidone, atrazine, diclofenac and naproxen) by the laccase- HBT system in our study.

It is interesting to note that while the fungal enzyme (laccase) was able to degrade some of the TrOC well-known to be resistant to bacterial degradation such as diclofenac, triclosan, naproxen and atrazine, it achieved low removal of some other compounds (such as ibuprofen, gemfibrozil and amitriptyline) consistently reported to be well removed (biodegraded) by conventional (bacteria dominated) MBRs (Hai et al., 2011; Nguyen et al., 2012; Tadkaew et al., 2011). This is discussed further in Section 3.3.

\subsection{Performance stability of $M B R$}

The seed sludge for the lab-scale MBRs in the current study was sourced from MBRs treating TrOC, and the MBRs were operated under stable temperature, $\mathrm{pH}, \mathrm{DO}$ and organic loading conditions (Section 2.4). Under the applied organic loading and MLSS sampling pattern (for weekly determination of MLSS/MLVSS, fungal/bacterial count and biomass laccase activity, and determination of amount of TrOC adsorbed on biosolids), the MLSS in the MBRs remained stable around $3 \mathrm{~g} / \mathrm{L}$. Under the applied low flux and vigorous aeration (Section 2.4), severe membrane fouling, causing TMP build-up, did not occur (data not shown), confirming stable hydraulic performance of the membrane. Accordingly, the fungus-augmented MBR showed good and stable performance with respect to the basic water quality parameters TOC and TN 
(Table 1). The addition of the mediator (HBT) appeared not to adversely affect the biological stability (e.g. in terms of MLVSS/MLSS ratio and TOC/TN removal). This confirms that the TrOC removal performance of the MBR was evaluated at stable conditions. Notably, in good agreement with a previous study (Nguyen et al., 2012), the basic operating and water quality parameters for the conventional MBR in the current study were also stable (data not shown).

\section{[TABLE 1]}

In good agreement with a previous study (Yang et al., 2013a), the viable fungal and bacterial count in the fungus-augmented MBR supernatant varied over the operating period (Table 1). It is noted that fungi prefer to grow in pellet form in suspension, and, thus, monitoring the fungal count in the mixed liquor supernatant sample may not accurately reflect the fungal concentration in the MBR. Nevertheless, monitoring the fungal count serves the important purpose of confirming the presence of viable fungi in the MBR throughout the operating period.

Consistent with the observations made in previous studies on continuous flow fungal reactors (Blánquez et al., 2008; Yang et al., 2013a), laccase activity was only occasionally detected in the mixed liquor supernatant (data not shown). This could be attributed to the previously reported factors such as: i) bacterial denaturation (Libra et al., 2003), as would be expected in real wastewater conditions, and ii) passage of laccase $(59-110 \mathrm{kDa})$ through the microfiltration membrane along with permeate (Hai et al., 2012b; Yang et al., 2013a). Nevertheless, the consistent detection of laccase activity in the MBR biomass (Table 1) confirmed the active presence of the white-rot fungi $T$. versicolor that was originally inoculated into the seed sludge source MBR.

\subsection{TrOC removal by fungus-augmented MBR}




\subsubsection{Batch enzymatic test vs. MBR operation}

Figure 2 presents the removal of $30 \mathrm{TrOC}$ by the fungus-augmented MBR. For the TrOC that were degraded with an efficiency of over $50 \%$ by crude enzyme solution in batch tests, the fungus-augmented MBR maintained high removal (80\% - complete) of all of them (except diclofenac with a removal of ca. 50\%) (Figure 2). Furthermore, of the 18 TrOC showing limited enzymatic degradation (negligible - 50\%), ten were removed with an efficiency of over $80 \%$ by the fungus-augmented MBR (Figure 2). Degradation of some compounds, namely, gemfibrozil (24\%), amitriptyline (28\%), primidone (40\%), salicylic acid (77\%), enterolactone (93\%) and oxybenzone $(95 \%)$ in the batch enzymatic tests was only obtained with the addition of the mediator (Figure 1), while the fungus-augmented MBR achieved their high removal (> 90\%) without mediator dosing (Figure 2).

\section{[FIGURE 2]}

Data from this study also highlighted the better removal performance of a fungus-augmented MBR (white-rot fungus + bacteria) compared to a conventional MBR. As shown in Table 2, the fungus-augmented MBR achieved better removal of six compounds, namely, fenoprop, clofibric acid, pentachlorophenol, ketoprofen, diclofenac and naproxen that are all well-known compounds resistant to bacterial degradation (Hai et al., 2011; Nguyen et al., 2012; Tadkaew et al., 2011). Of further interest is the fact that the removal of fenoprop, clofibric acid, pentachlorophenol and ketoprofen, as obtained by the fungus-augmented MBR, was better than that by both batch fungal enzymatic tests and conventional (bacterial) MBR (Figure 2 and Table 2). This observation points to a synergistic effect achievable by combining a mixed culture of bacteria and white-rot fungus. Our observation is in line with another study where enhanced 
removal of three pesticides from their mixture was demonstrated by a mixed culture of bacteria and white-rot fungus as compared to bacteria or white-rot fungus -only cultures (Hai et al., 2012a).

\section{[TABLE 2]}

\subsubsection{Role of biosorption and biodegradation}

Given the very low vapour pressure or Henry's constant $(\mathrm{H})$ and low $\mathrm{H} / \log \mathrm{D}$ ratio of the TrOC selected in this study (Supplementary Data Table 1), their removal by volatilization is expected to be negligible. Therefore, biosorption and biodegradation/transformation can be considered as the major mechanisms of TrOC removal by MBR. One may wonder whether the improved TrOC removal by the fungus-augmented $\mathrm{MBR}$ as compared to that in the batch enzymatic test was due mainly to the adsorption of the compounds on biomass in the former. However, for several of these compounds (e.g. fenoprop, clofibric acid, amitriptyline, salicylic acid, ketoprofen, and enterolactone) biosorption is likely to have played a limited role as they are hydrophilic $(\log \mathrm{D}$ $<3(\mathrm{pH}=5)$, as marked on Figure 2). Indeed, the dominant role of biodegradation can be demonstrated by Figure 3 which plots the adsorption of the 30 TrOC on fungus-augmented MBR biomass at the mid-point and the end of the operating period. Figure 3 confirms the gradual reduction of the concentration of the TrOC on fungus-augmented MBR biomass. The role of biodegradation is also supported by Figure 4 which depicts the overall fate of the selected TrOC during fungus-augmented MBR treatment. The total loading of each TrOC and the amount passing through the system untransformed along with permeate was calculated considering the feed/permeate volume, TrOC concentration in each and the experimental duration. The difference between the amounts fed and lost with permeate indicated the amount 'retained', i.e., that went through transformation or simply remained adsorbed on biomass. The residual amount 
of untransformed TrOC on biomass was calculated considering the MLSS concentration, reactor volume and the residual TrOC concentration on biomass at the end of the experiment, and finally, the percentage of biodegradation/transformation was estimated.

Biosorption may facilitate further biodegradation (Tadkaew et al., 2011; Wijekoon et al., 2013). However, in this study, the improved removal by the fungus-augmented MBR (Figure 2), as compared to in vitro enzymatic degradation (Figure 1), was not merely due to adsorption on biomass but due to progressively fortified biodegradation. This is confirmed by the data regarding the concentration of the TrOCs on MBR biomass, coupled with the fact that no biomass was withdrawn from the system except for sampling. It is noted that, irrespective of the hydrophobicity, the TrOC for which the MBR achieved better aqueous phase removal than that observed during batch enzymatic degradation tests, biosorption accounted for less than $5 \%$ of the overall fate (Figure 4). Our observation regarding the major role of fungal biodegradation in TrOC removal is in good agreement with previous reports (García-Galán et al., 2011; Yang et al., 2013a; Zhang \& Geißen, 2012).

\section{[FIGURE 3]}

\section{[FIGURE 4]}

\subsection{Effect of continuous dosing of mediator to fungus-augmented MBR}

Different levels of improvement (22\% (ametryn) to 93\% (atrazine)) in degradation were observed for 11 TrOC during batch tests due to the addition of the mediator in crude enzyme solution (Figure 1). Of them, all TrOC except atrazine, ametryn and diclofenac were already well removed by the fungus-augmented MBR without mediator dosing (Figure 2), indicating the fact that fungal removal was enhanced due to bacterial presence (Section 3.3.1). The investigation 
with continuous dosing of mediator to fungus-augmented MBR was conducted to check whether any improvement in the remaining TrOC removal could be achieved.

No significant difference in removal by the MBR with/without mediator dosing was observed for other TrOC (data not shown); therefore discussion here will focus on the removal of the aforementioned three compounds, namely, atrazine, ametryn and diclofenac. Only the removal of diclofenac was significantly improved by mediator dosing to MBR (Figure 5). The removal of atrazine and ametryn did not improve even after doubling the mediator dose to $10 \mu \mathrm{M}$ (data not shown). The improvement in enzymatic degradation of ametryn as achieved during batch tests due to the mediator addition was limited ( $20 \%$ improvement with the final level of degradation not exceeding 30\%). However, as high as $93 \%$ improvement in enzymatic degradation of atrazine was achieved due to mediator addition during batch tests (Figure 1). Therefore, no increase in atrazine removal by the MBR after mediator addition necessitates further discussion.

\section{[FIGURE 5]}

No study systematically comparing the performance of mediator-enhanced laccase system in sterile/non-sterile and batch/continuous flow systems could be identified. However, some inferences regarding the cause of inefficient removal of atrazine by the MBR can be drawn from the available batch studies. Mediators such as HBT can cause inactivation of laccase by free radical attack on the catalytic site of the enzyme and consequently slow down the compound conversion rate, thus reducing the positive impact of mediator addition on enzymatic degradation (Kim \& Nicell, 2006). In this study, a higher atrazine removal was achieved due to HBT addition during batch tests (Figure 1) despite the fact that the laccase activity of the batch test solution within $24 \mathrm{~h}$ of HBT addition dropped by $c a .50 \%$ (as compared to no drop in the test solution 
without HBT) (data not shown). However, this laccase activity lowering effect of HBT addition may have been more significant in case of the MBR where the supernatant laccase activity was mostly at a non-detectable level (although the laccase activity in biomass was always detectable, Table 1), while during batch tests the initial laccase activity of the test solution was $35 \mu \mathrm{M} / \mathrm{min}$ (Section 2.3). Another possible reason may be the difference between the wastewater matrix in the batch test and MBR. It is worth reiterating that, in this study, the crude enzyme solution was obtained by growing the pure culture of $T$. versicolor in MEB, while the MBR was continuously fed with a wastewater composed of MEB along with thiamine and some salts, namely, $\mathrm{KH}_{2} \mathrm{PO}_{4}$, $\mathrm{MgSO}_{4}$ and $\mathrm{FeSO}_{4}$ (Section 2.2). Furthermore, in contrast to the enzyme solution used in the batch tests, the bioreactor mixed liquor was characterized by higher suspended solids. In this context, it is notable that the effect of wastewater constituents on the performance of laccasemediator system has been reported previously in the literature. For example, the presence of humic acid in the media containing laccase and the mediator syringaldehyde reduced the degradation of the fungicide cyprodinil by $12 \%$ (Kang et al., 2002). The presence of ions such as $\mathrm{Cu}^{2+}$ and $\mathrm{Fe}^{3+}$ in the laccase solution caused significant reduction in the conversion of triclosan (Kim \& Nicell, 2006). These ions may interrupt the electron transport between laccase and mediator resulting in reduction of laccase-mediator performance.

\subsection{Effluent toxicity}

TrOC transformation via white-rot fungi often leads to detoxification (Jelic et al., 2012). On the other hand, increase in toxicity of white-rot fungi-treated media containinig TrOC has also been reported in the literature. For example, 1,2- hydroxy ibuprofen, the main metabolite during ibuprofen degradation by T. versicolor, was more toxic than ibuprofen (Marco-Urrea et al., 2009). Increased toxicity of the treated media is a particular concern associated with the addition 
of mediators (Kim \& Nicell, 2006). Therefore, we tested the toxicity of the MBR permeate relative to the feed wastewater. A ToxScreen3 assay (Section 2.5) revealed no significant increase in the toxicity of the effluent during MBR treatment of the synthetic wastewater (relative toxic unit of $4.1 \pm 0.3$ and $4.6 \pm 1.1$, respectively). Fungus-augmented MBR, therefore, can be recommended to more efficiently remove $\mathrm{TrOC}$ without the production of toxic metabolites; however, a risk assessment should be performed for each specific process (e.g. wastewater matrix and TrOC types and concentrations) given the contrasting data in the literature.

\section{Conclusion}

Results in this study highlight that a mixed culture of bacteria and a white-rot fungus in a fungusaugmented MBR can achieve better TrOC removal than a system containing fungus or bacteria alone. The major role of biodegradation was confirmed for all TrOC for which the MBR system achieved high aqueous phase removal. Redox mediators can enhance the performance of fungal enzyme (laccase); however, compared to batch tests, due to lower enzymatic activity level and more complex wastewater matrix, limited improvement in removal due to mediator dosing may be achieved by the MBR for compounds originally highly resistant to fungal degradation.

\section{Acknowledgment}

PhD scholarships to Luong N. Nguyen and Shufan Yang from the University of Wollongong, Australia are greatly appreciated. Mitsubishi Rayon Engineering, Japan is thanked for the provision of the membrane module. 


\section{References}

[1] Blánquez, P., Guieysse, B. 2008. Continuous biodegradation of $17 \beta$-estradiol and $17 \alpha-$ ethynylestradiol by Trametes versicolor. J. Hazard. Mater., 150, 459-462.

[2] Blánquez, P., Sarrà, M., Vicent, T. 2008. Development of a continuous process to adapt the textile wastewater treatment by fungi to industrial conditions. Process Biochem., 43, 1-7.

[3] Boonyaroj, V., Chiemchaisri, C., Chiemchaisri, W., Theepharaksapan, S., Yamamoto, K. 2012. Toxic organic micro-pollutants removal mechanisms in long-term operated membrane bioreactor treating municipal solid waste leachate. Bioresource Technol, 113, 174-180.

[4] Cajthaml, T., Křesinová, Z., Svobodová, K., Möder, M. 2009. Biodegradation of endocrinedisrupting compounds and suppression of estrogenic activity by ligninolytic fungi. Chemosphere, 75, 745-750.

[5] CheckLight. 2010. PCB-TOX (ToxScreen 3) Test Kit User Guide, CheckLight LTD, QiryatTivon.

[6] Chivukula, M., Renganathan, V. 1995. Phenolic azo dye oxidation by laccase from Pyricularia oryzae. Appl. Environ. Microbiol., 61, 4374-7.

[7] Coniglio, A., Galli, C., Gentili, P., Vadalà, R. 2008. Oxidation of amides by laccasegenerated aminoxyl radicals. J. Mol. Catal. B: Enzym., 50, 40-49.

[8] D'Acunzo, F., Galli, C., Gentili, P., Sergi, F. 2006. Mechanistic and steric issues in the oxidation of phenolic and non-phenolic compounds by laccase or laccase-mediator systems. The case of bifunctional substrates. New J. Chem., 30, 583-591.

[9] Eaton, A.D., Clescerl, L.S., Rice, E.W., Greenberg, A.E. 2005. Standard Methods for Examination of Water \& Wastewater. 21st ed, American Public Health Association. Washington, D.C.

[10] García-Galán, M.J., Rodríguez-Rodríguez, C.E., Vicent, T., Caminal, G., Díaz-Cruz, M.S., Barceló, D. 2011. Biodegradation of sulfamethazine by Trametes versicolor: Removal from sewage sludge and identification of intermediate products by UPLC-QqTOF-MS. Sci. Total Environ., 409, 5505-5512.

[11] Hai, F.I., Nghiem, L.D., Khan, S.J., Price, W.E., Yamamoto, K. 2013. "Wastewater reuse: Removal of Emerging Trace Organic Contaminants" in Membrane Biological reactors, (eds. Hai, FI, Yamamoto, K. and Lee, C-H), IWA publishing, UK, 2013 (ISBN: 9781780400655), pp 163-203.

[12] Hai, F.I., Modin, O., Yamamoto, K., Fukushi, K., Nakajima, F., Nghiem, L.D. 2012 a. Pesticide removal by a mixed culture of bacteria and white-rot fungi. J Taiwan Inst Chem Eng, 43, 459-462.

[13] Hai, F.I., Tessmer, K., Nguyen, L.N., Kang, J., Price, W.E., Nghiem, L.D. 2011. Removal of micropollutants by membrane bioreactor under temperature variation. J Membrane Sci, 383, 144-151.

[14] Hai, F.I., Yamamoto, K., Nakajima, F., Fukushi, K. 2012b. Application of a GAC-coated hollow fiber module to couple enzymatic degradation of dye on membrane to whole cell biodegradation within a membrane bioreactor. J Membrane Sci, 389, 67-75.

[15] Hai, F.I., Yamamoto, K., Nakajima, F., Fukushi, K. 2009. Factors governing performance of continuous fungal reactor during non-sterile operation - The case of a membrane bioreactor treating textile wastewater. Chemosphere, 74, 810-817. 
[16] Hata, T., Shintate, H., Kawai, S., Okamura, H., Nishida, T. 2010. Elimination of carbamazepine by repeated treatment with laccase in the presence of 1hydroxybenzotriazole. J. Hazard. Mater., 181, 1175-1178.

[17] Jelic, A., Cruz-Morató, C., Marco-Urrea, E., Sarrà, M., Perez, S., Vicent, T., Petrović, M., Barcelo, D. 2012. Degradation of carbamazepine by Trametes versicolor in an air pulsed fluidized bed bioreactor and identification of intermediates. Water Res, 46, 955-964.

[18] Kang, K.-H., Dec, J., Park, H., Bollag, J.-M. 2002. Transformation of the fungicide cyprodinil by a laccase of Trametes villosa in the presence of phenolic mediators and humic acid. Water Res, 36, 4907-4915.

[19] Kim, Y.J., Nicell, J.A. 2006. Laccase catalysed oxidation of aqueous triclosan. J. Chem. Technol. Biotechnol., 81, 1344-1352.

[20] Libra, J.A., Borchert, M., Banit, S. 2003. Competition strategies for the decolorization of a textile-reactive dye with the white-rot fungi Trametes versicolor under non-sterile conditions. Biotechnol. Bioeng., 82, 736-744.

[21] Lloret, L., Eibes, G., Feijoo, G., Moreira, M.T., Lema, J.M. 2012. Degradation of estrogens by laccase from Myceliophthora thermophila in fed-batch and enzymatic membrane reactors. J Hazard Mater, 213-214, 175-183.

[22] Marco-Urrea, E., Perez-Trujillo, M., Vicent, T., Caminal, G. 2009. Ability of white-rot fungi to remove selected pharmaceuticals and identification of degradation products of ibuprofen by Trametes versicolor. Chemosphere, 74, 765-72.

[23] Mougin, C., Laugero, C., Asther, M., Chaplain, V. 1997. Biotransformation of s-triazine herbicides and related degradation products in liquid cultures by the white- rot fungus Phanerochaete chrysosporium. Pestic. Sci., 49, 169-177.

[24] Navaratna, D., Elliman, J., Cooper, A., Shu, L., Baskaran, K., Jegatheesan, V. 2012. Impact of herbicide Ametryn on microbial communities in mixed liquor of a membrane bioreactor (MBR). Bioresource Technol, 113, 181-190.

[25] Nguyen, L.N., Hai, F.I., Kang, J., Price, W.E., Nghiem, L.D. 2012. Removal of trace organic contaminants by a membrane bioreactor-granular activated carbon (MBR-GAC) system. Bioresource Technol, 113, 169-173.

[26] Rodarte-Morales, A.I., Feijoo, G., M.Teresa, M., Lema, J. 2012. Evaluation of two operational regimes fed-batch and continuous for the removal of pharmaceuticals in a fungal stirred tank reactor. Che. Eng. Trans, 27, 151-156.

[27] Snyder, S.A. 2008. Occurrence, Treatment, and Toxicological Relevance of EDCs and Pharmaceuticals in Water. Ozone. Sci. Eng., 30, 65-69.

[28] Tadkaew, N., Hai, F.I., McDonald, J.A., Khan, S.J., Nghiem, L.D. 2011. Removal of trace organics by MBR treatment: The role of molecular properties. Water Res, 45, 2439-2451.

[29] Tran, N.H., Urase, T., Kusakabe, O. 2010. Biodegradation characteristics of pharmaceutical substances by whole fungal culture Trametes versicolor and its laccase. J Water Environ Technol, 8, 125-140.

[30] Ulitzur, S., Lahav, T., Ulitzur, N. 2002. A novel and sensitive test for rapid determination of water toxicity. Environ Toxicol, 17, 291-296.

[31] Wijekoon, K.C., Fujioka, T., McDonald, J.A., Khan, S.J., Hai, F.I., Price, W.E., Nghiem, L.D. 2013. Removal of N-nitrosamines by an aerobic membrane bioreactor. Bioresource Technology.

[32] Yang, S., Hai, F.I., Nghiem, L.D., Nguyen, L.N., Roddick, F., Price, W.E. 2013a. Removal of bisphenol A and diclofenac by a novel fungal membrane bioreactor operated under 
non-sterile conditions. Int. Biodeterior. Biodegradation, http://dx.doi.org/10.1016/j.ibiod.2013.03.012.

[33] Yang, S., Hai, F.I., Nghiem, L.D., Price, W.E., Roddick, F., Moreira, M.T., Magram, S.F. 2013b. Understanding the factors controlling the removal of trace organic contaminants by white-rot fungi and their lignin modifying enzymes: a critical review. Bioresource Technol, 141, 97-108.

[34] Zhang, Y., Geißen, S.-U. 2012. Elimination of carbamazepine in a non-sterile fungal bioreactor. Bioresource Technol, 112, 221-227. 


\section{LIST OF TABLES}

Table 1: Basic biological performance of the fungus-augmented MBR with/without continuous dosing of a redox mediator (1-hydroxy benzotriazole) $(5 \mu \mathrm{M})$.

\begin{tabular}{|c|c|c|c|c|c|c|}
\hline Process & $\begin{array}{c}\text { MLVSS/ } \\
\text { MLSS } \\
\text { ratio }\end{array}$ & $\begin{array}{l}\text { Fungal count } \\
\left(10^{6} \mathrm{CFU} / \mathrm{mL}\right)\end{array}$ & $\begin{array}{l}\text { Bacterial count } \\
\left(10^{6} \mathrm{CFU} / \mathrm{mL}\right)\end{array}$ & $\begin{array}{c}\text { Biomass } \\
\text { laccase activity } \\
(\mu \mathrm{M} / \mathrm{min} / \mathrm{g} \\
\mathrm{MLSS})\end{array}$ & $\begin{array}{c}\text { TOC } \\
\text { removal } \\
(\%)\end{array}$ & $\begin{array}{c}\mathrm{TN} \\
\text { removal } \\
(\%)\end{array}$ \\
\hline Without mediator & $\begin{array}{l}0.67 \pm 0.1 \\
(n=15)\end{array}$ & $\begin{array}{c}125 \pm 71 \\
(n=15)\end{array}$ & $\begin{array}{c}122 \pm 69 \\
(n=15)\end{array}$ & $\begin{array}{l}45 \pm 23 \\
(n=15)\end{array}$ & $\begin{array}{l}97 \pm 2 \\
(n=17)\end{array}$ & $\begin{array}{l}75 \pm 12 \\
(n=15)\end{array}$ \\
\hline With mediator & $\begin{array}{c}0.75 \pm 0.1 \\
(n=6)\end{array}$ & $\begin{array}{c}100 \pm 38 \\
(n=6)\end{array}$ & $\begin{array}{c}125 \pm 54 \\
(n=6)\end{array}$ & $\begin{array}{l}59 \pm 8 \\
(n=6)\end{array}$ & $\begin{array}{c}97 \pm 2 \\
(n=11)\end{array}$ & $\begin{array}{c}79.0 \pm 12.5 \\
(n=11)\end{array}$ \\
\hline
\end{tabular}


Table 2: Removal efficiency (average \pm standard deviation, $n=14$ ) of six TrOC consistently showing better aqueous phase removal by the fungus-augmented MBR than the conventional MBR

\begin{tabular}{ccc}
\hline & \multicolumn{2}{c}{ Removal efficiency $(\%)$} \\
TrOC & $57 \pm 25$ & Conventional MBR \\
\cline { 2 - 3 } Fenoprop & $65 \pm 17$ & $20 \pm 15$ \\
Clofibric acid & $92 \pm 5$ & $25 \pm 3$ \\
Pentachlorophenol & $94 \pm 2$ & $60 \pm 10$ \\
Ketoprofen & & $65 \pm 13$ \\
Diclofenac & $50 \pm 9$ & $15 \pm 10$ \\
Naproxen & $>99$ & $45 \pm 15$
\end{tabular}




\section{LIST OF FIGURES}

Figure 1: Removal of 30 TrOC by the crude enzyme extract (laccase) with and without addition of a mediator (1-hydroxy benzotriazole) under continuous rotational shaking (70 rpm) and at 28 ${ }^{\circ} \mathrm{C}$. Error bar represents the standard deviation of three samples.

Figure 2: Removal of $30 \mathrm{TrOC}$ by the fungus-augmented MBR. Error bar represents the standard deviation of 14 samples. Operating conditions of MBR are presented in Section 2.4

Figure 3: Adsorption of 30 TrOC on fungus-augmented MBR biomass at the mid-point and the end of the operating period.

Figure 4: Fate of the selected TrOC during fungus-augmented MBR treatment. Operating conditions of MBR are presented in Section 2.4.

Figure 5: Removal of diclofenac, ametryn and atrazine by the fungus-augmented MBR with and without addition of a mediator (1-hydroxy benzotriazole) at a concentration of $5 \mu \mathrm{M}$. Each data point corresponds to the average of duplicate samples with less than $5 \%$ variation in between. 


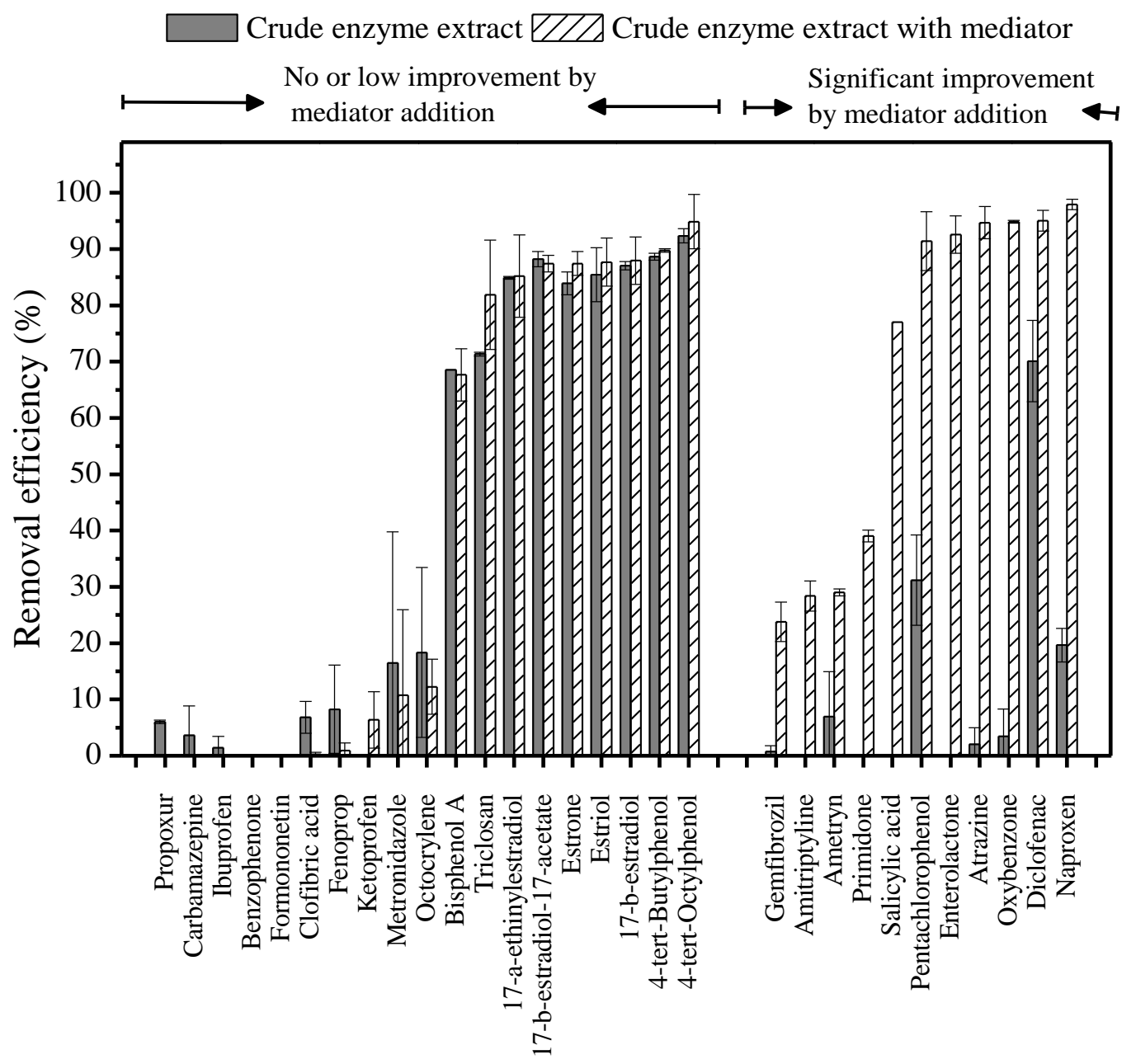

Figure 1 


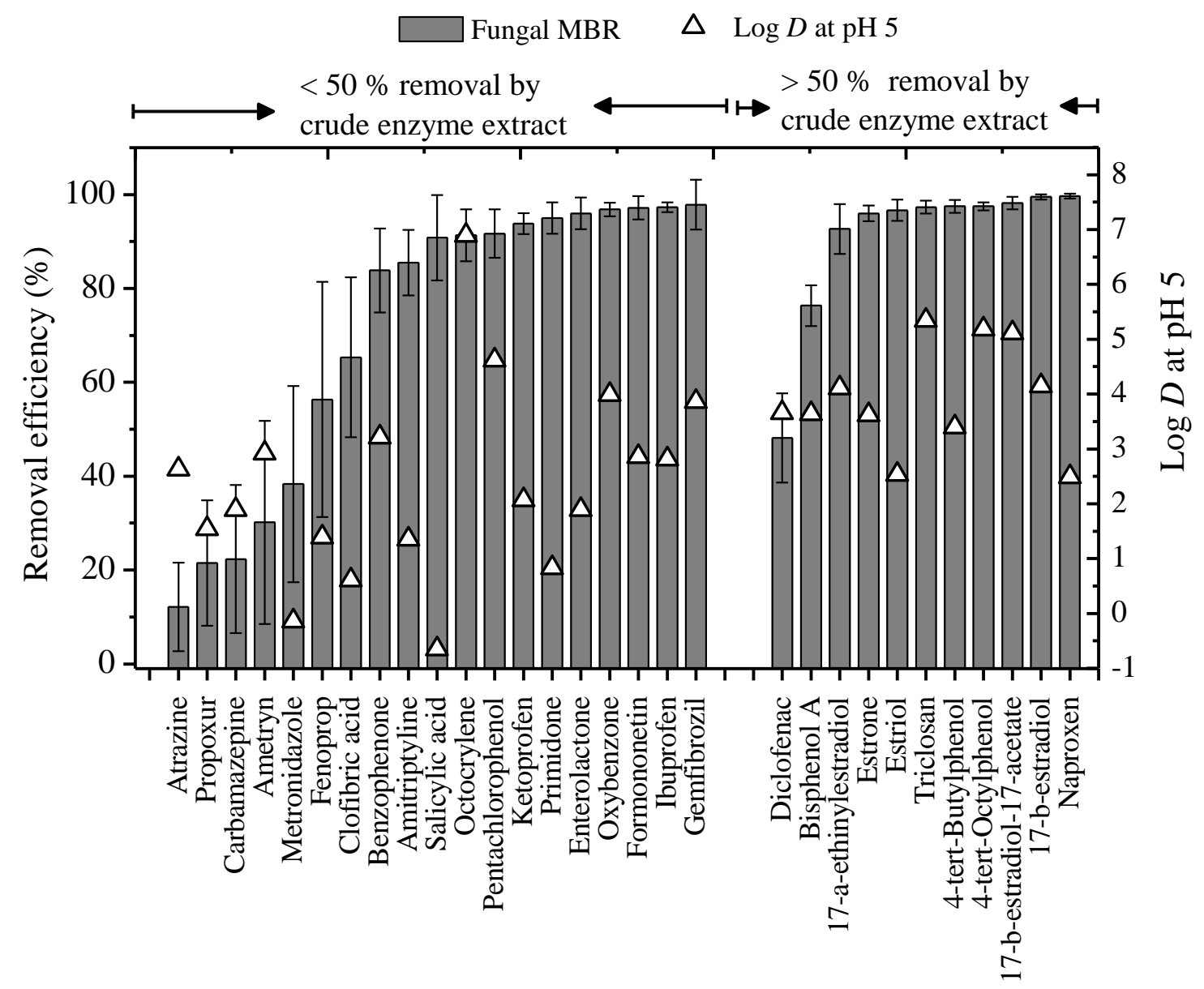

Figure 2 


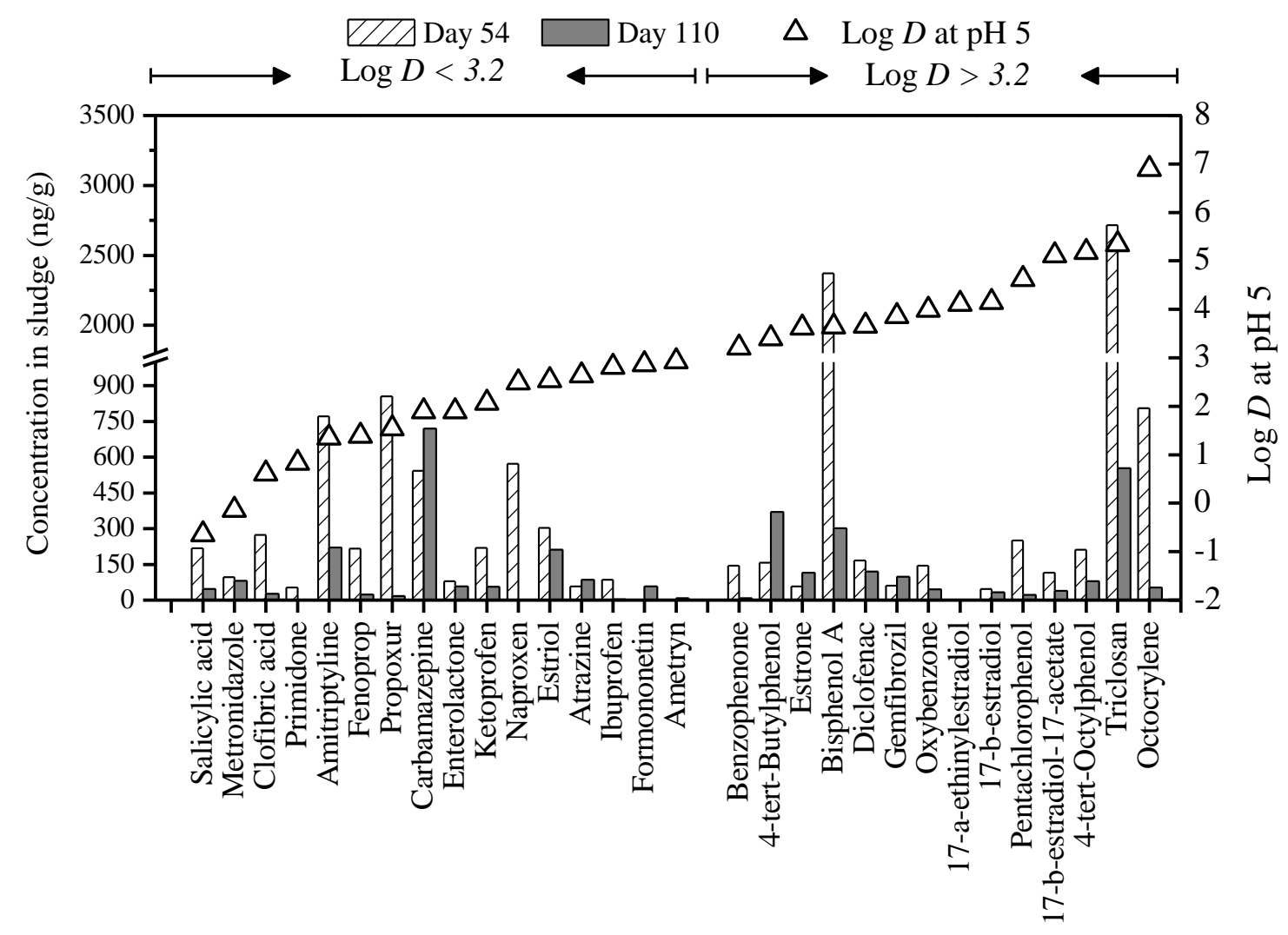

Figure 3 


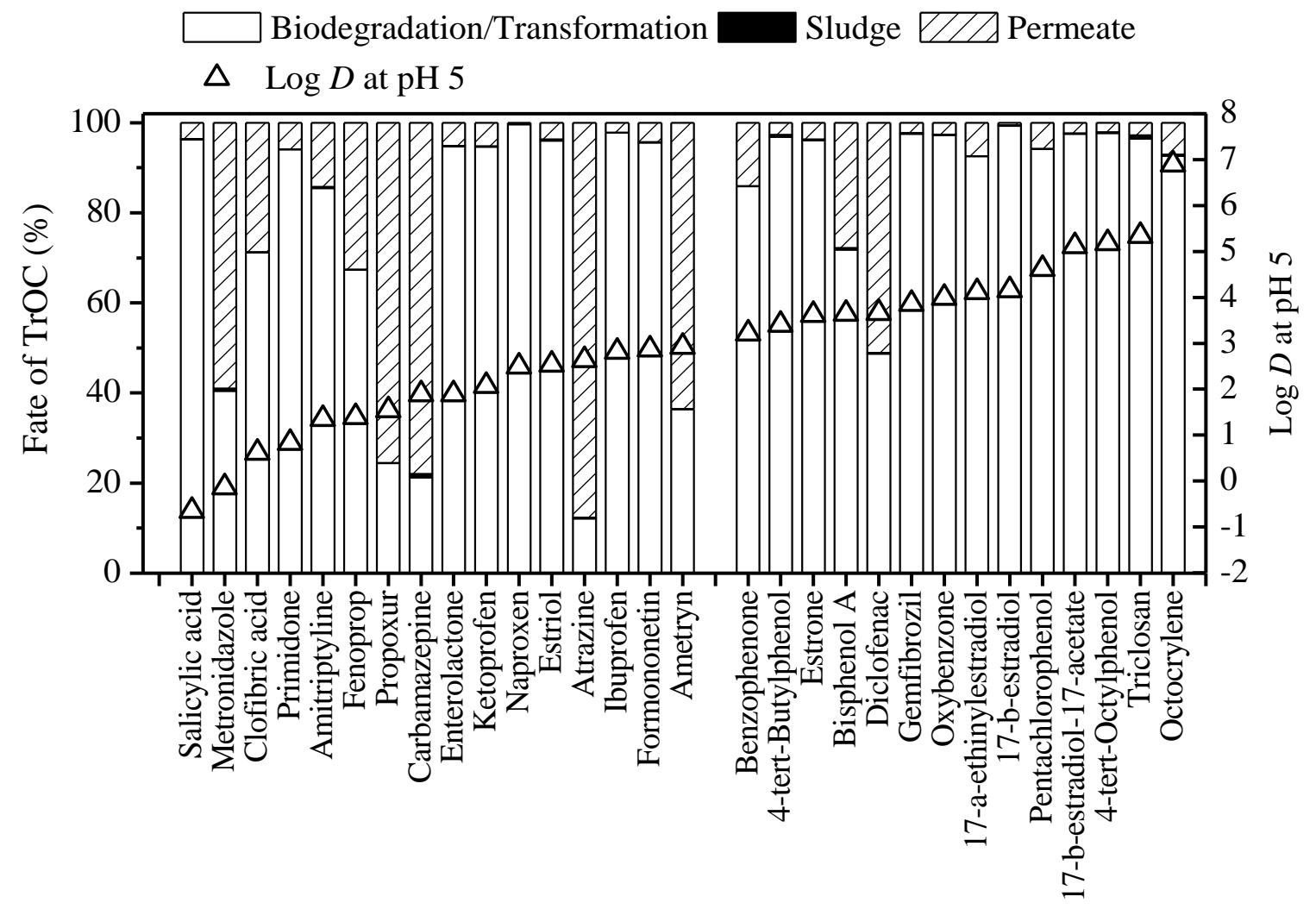

Figure 4 


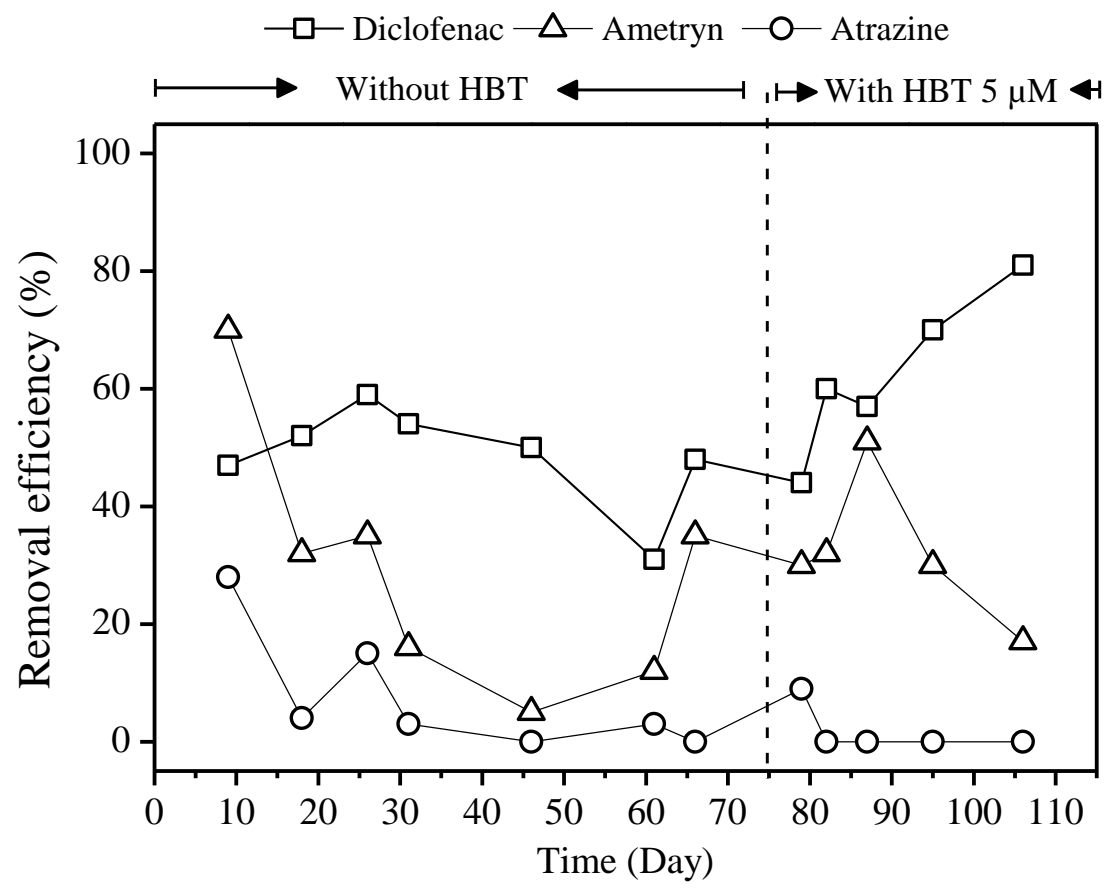

Figure 5 


\section{Removal of trace organic contaminants by an MBR comprising a mixed culture of bacteria and white-rot fungi}

Luong N. Nguyen ${ }^{a}$, Faisal I. Hai ${ }^{a^{*}}$, Shufan Yang ${ }^{a}$, Jinguo Kang ${ }^{b}$, Frederic D. L. Leusch ${ }^{c}$, Felicity Roddick ${ }^{d}$, William E. Price ${ }^{b}$, and Long D. Nghiem ${ }^{a}$

${ }^{a}$ Strategic Water Infrastructure Laboratory, School of Civil, Mining and Environmental Engineering, University of Wollongong, Wollongong, NSW 2522, Australia

${ }^{\mathrm{b}}$ Strategic Water Infrastructure Laboratory, School of Chemistry, University of Wollongong, Wollongong, NSW 2522, Australia

${ }^{\mathrm{c}}$ Smart Water Research Centre, School of Environment, Griffith University, Southport, QLD 4222, Australia

${ }^{\mathrm{d}}$ School of Civil, Environmental and Chemical Engineering, RMIT University, Melbourne, Victoria 3001, Australia

* Corresponding author: Faisal I. Hai, Email: faisal@uow.edu.au; Ph: +61 242213054 
Table S1: Physicochemical properties of the selected trace organic contaminants (TrOC).

\begin{tabular}{|c|c|c|c|c|c|c|}
\hline Category & $\begin{array}{c}\text { Compound } \\
\text { (CAS number) }\end{array}$ & $\begin{array}{l}\text { Molecular } \\
\text { weight } \\
\left(\mathrm{g} \mathrm{mol}^{-1}\right)\end{array}$ & $\begin{array}{l}\log \\
\mathrm{K}_{\mathrm{OW}}{ }^{\mathrm{a}}\end{array}$ & $\begin{array}{l}\log \mathrm{D} \\
(\mathrm{pH} 5)^{\mathrm{a}}\end{array}$ & $\begin{array}{l}\text { Dissociati } \\
\text { on } \\
\text { constant } \\
(\mathrm{pKa})^{\mathrm{a}}\end{array}$ & Chemical structure \\
\hline \multirow{7}{*}{ 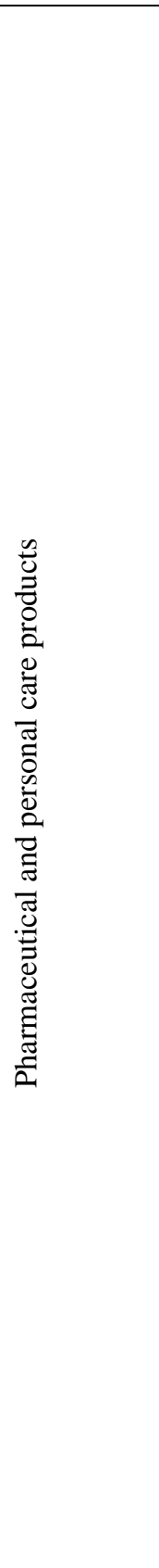 } & $\begin{array}{l}\text { Ibuprofen } \\
\left(\mathrm{C}_{13} \mathrm{H}_{18} \mathrm{O}_{2}\right) \\
(5687-27-1)\end{array}$ & 206.28 & $\begin{array}{c}3.50 \pm \\
0.23\end{array}$ & 2.81 & $\begin{array}{c}4.41 \pm \\
0.10\end{array}$ & \\
\hline & $\begin{array}{c}\text { Naproxen } \\
\left(\mathrm{C}_{14} \mathrm{H}_{14} \mathrm{O}_{3}\right) \\
(22204-53-1)\end{array}$ & 230.26 & $\begin{array}{c}2.88 \pm \\
0.24\end{array}$ & 2.49 & $\begin{array}{c}4.84 \pm \\
0.30\end{array}$ & \\
\hline & $\begin{array}{l}\text { Ketoprofen } \\
\left(\mathrm{C}_{16} \mathrm{H}_{14} \mathrm{O}_{3}\right) \\
(22071-15-4)\end{array}$ & 254.28 & $\begin{array}{c}2.91 \pm \\
0.33\end{array}$ & 2.07 & $\begin{array}{c}4.23 \pm \\
0.10\end{array}$ & \\
\hline & $\begin{array}{c}\text { Diclofenac } \\
\left(\mathrm{C}_{14} \mathrm{H}_{11} \mathrm{Cl}_{2} \mathrm{NO}_{2}\right) \\
(15307-86-5)\end{array}$ & 296.15 & $\begin{array}{c}4.55 \pm \\
0.57\end{array}$ & 3.66 & $\begin{array}{c}4.18 \pm \\
0.10 \\
\\
-2.26 \pm \\
0.50\end{array}$ & \\
\hline & $\begin{array}{c}\text { Primidone } \\
\left(\mathrm{C}_{12} \mathrm{H}_{14} \mathrm{~N}_{2} \mathrm{O}_{2}\right) \\
(125-33-7)\end{array}$ & 218.25 & $\begin{array}{c}0.83 \pm \\
0.50\end{array}$ & 0.83 & $\begin{array}{c}12.26 \pm \\
0.40 \\
-1.07 \pm \\
0.40\end{array}$ & \\
\hline & $\begin{array}{c}\text { Carbamazepine } \\
\left(\mathrm{C}_{15} \mathrm{H}_{12} \mathrm{~N}_{2} \mathrm{O}\right) \\
(298-46-4)\end{array}$ & 236.27 & $\begin{array}{c}1.89 \pm \\
0.59\end{array}$ & 1.89 & $\begin{array}{c}13.94 \pm \\
0.20 \\
-0.49 \pm \\
0.20\end{array}$ & \\
\hline & $\begin{array}{c}\text { Salicylic acid } \\
\left(\mathrm{C}_{7} \mathrm{H}_{6} \mathrm{O}_{3}\right) \\
(69-72-7)\end{array}$ & 138.12 & $\begin{array}{c}2.01 \pm \\
0.25\end{array}$ & -0.65 & $\begin{array}{c}3.01 \pm \\
0.10\end{array}$ & \\
\hline
\end{tabular}




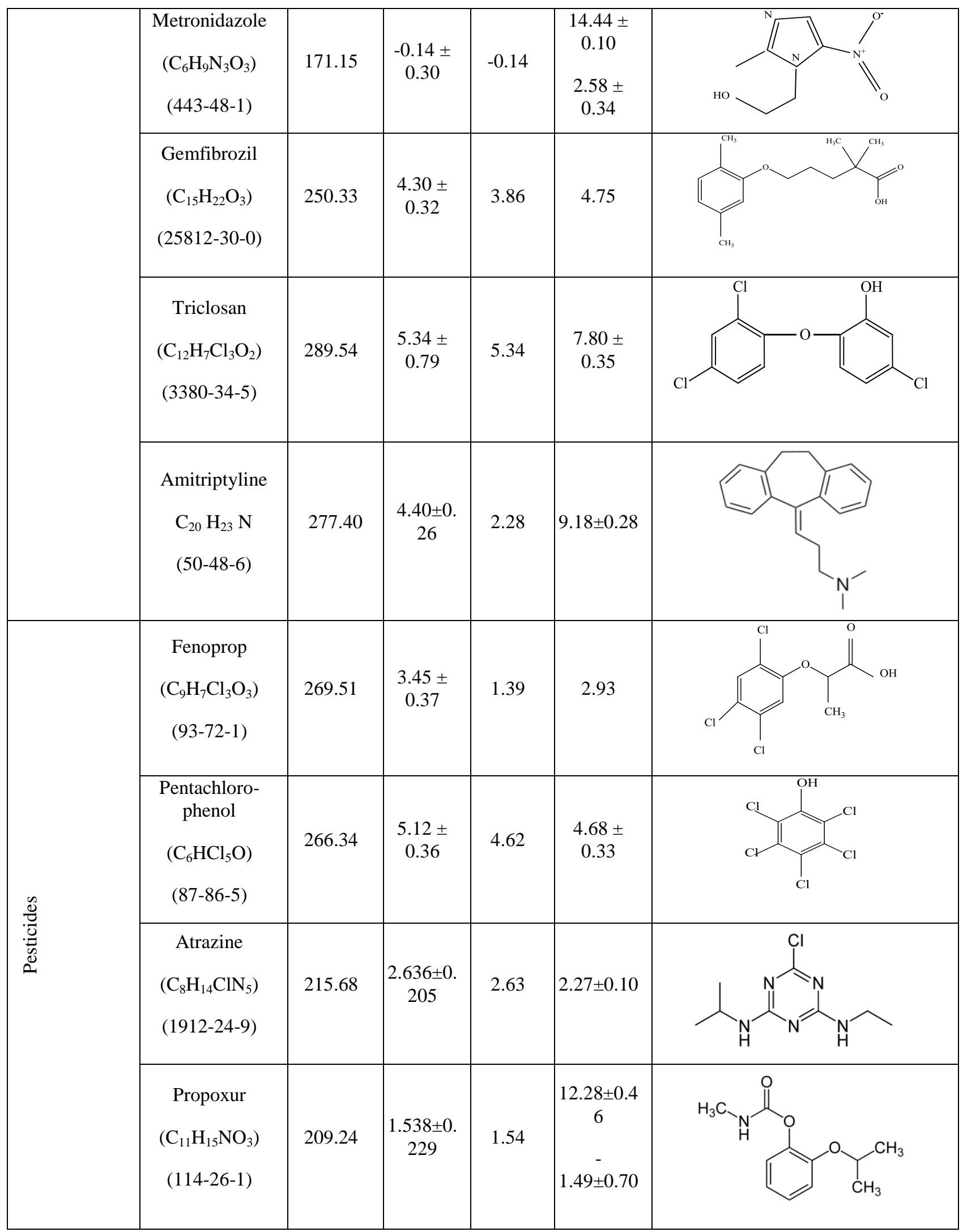




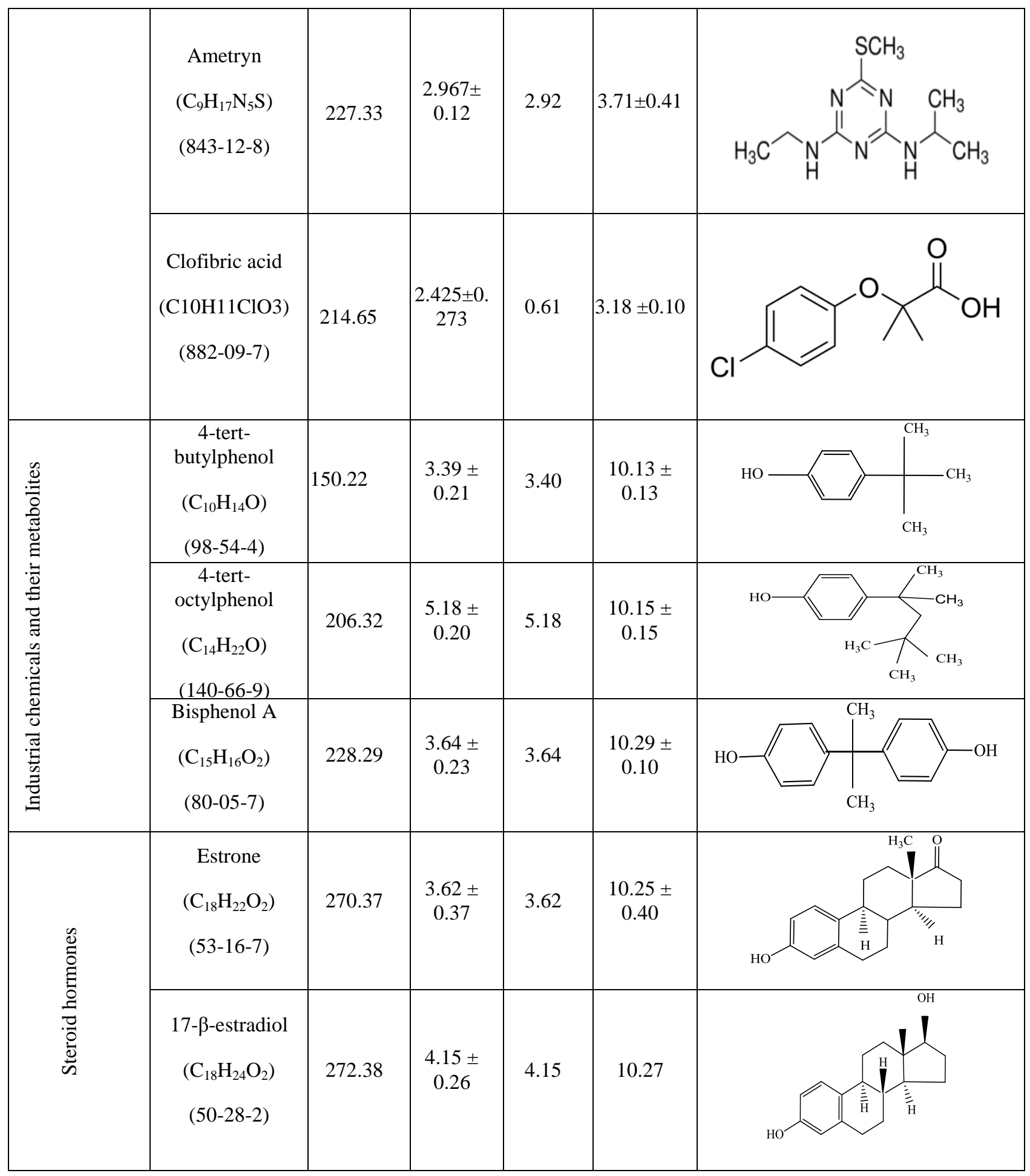




\begin{tabular}{|c|c|c|c|c|c|c|}
\hline & $\begin{array}{c}\text { 17- } \beta \text {-estradiol - } \\
\text { acetate } \\
\left(\mathrm{C}_{20} \mathrm{H}_{26} \mathrm{O}_{3}\right) \\
(1743-60-8)\end{array}$ & 314.42 & $\begin{array}{c}5.11 \pm \\
0.28\end{array}$ & 5.11 & $\begin{array}{c}10.26 \pm \\
0.60\end{array}$ & \\
\hline & $\begin{array}{c}17-\alpha \\
\text { ethinylestradiol } \\
\left(\mathrm{C}_{20} \mathrm{H}_{24} \mathrm{O}_{2}\right) \\
(57-63-6)\end{array}$ & 269.40 & $\begin{array}{c}4.10 \pm \\
0.31\end{array}$ & 4.11 & $\begin{array}{c}10.24 \pm \\
0.60\end{array}$ & \\
\hline & $\begin{array}{c}\text { Estriol (E3) } \\
\left(\mathrm{C}_{18} \mathrm{H}_{24} \mathrm{O}_{3}\right) \\
(50-27-1)\end{array}$ & 288.38 & $\begin{array}{c}2.53 \pm \\
0.28\end{array}$ & 2.53 & $\begin{array}{c}10.25 \pm \\
0.70\end{array}$ & \\
\hline \multirow{4}{*}{ 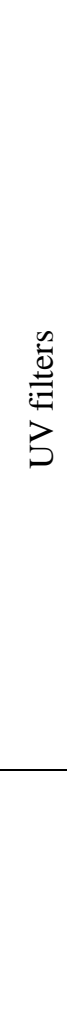 } & $\begin{array}{l}\text { Benzophenone } \\
\qquad \mathrm{C}_{13} \mathrm{H}_{10} \mathrm{O} \\
(119-61-9)\end{array}$ & 182.22 & $\begin{array}{c}3.21 \pm \\
0.29\end{array}$ & 3.21 & - & \\
\hline & $\begin{array}{c}\text { Oxybenzone } \\
\mathrm{C}_{14} \mathrm{H}_{12} \mathrm{O}_{3} \\
(131-57-7)\end{array}$ & 228.24 & $\begin{array}{c}3.99 \pm 0 . \\
36\end{array}$ & 3.89 & $7.56 \pm 0.35$ & \\
\hline & $\begin{array}{l}\text { Octocrylene } \\
\mathrm{C}_{24} \mathrm{H}_{27} \mathrm{~N} \mathrm{O}_{2} \\
(6197-30-4)\end{array}$ & 361.48 & $\begin{array}{c}6.89 \pm 0 . \\
33\end{array}$ & 6.89 & - & \\
\hline & $\begin{array}{l}\text { Formononetin } \\
\qquad \mathrm{C}_{16} \mathrm{H}_{12} \mathrm{O}_{4} \\
(485-72-3)\end{array}$ & 268.26 & $\begin{array}{c}2.86 \\
\pm 1.13\end{array}$ & 2.86 & $6.99 \pm 0.20$ & $\begin{array}{l}\mathrm{O} \\
\mathrm{I} \\
\mathrm{CH}_{3}\end{array}$ \\
\hline
\end{tabular}




\begin{tabular}{|l|c|c|c|c|c|c|}
\hline & Enterolactone & & & & \\
& $\mathrm{C}_{18} \mathrm{H}_{18} \mathrm{O}_{4}$ & 298.33 & $1.89 \pm$ \\
0.37 & 1.89 & $9.93 \pm 0.10$ & \\
$(78473-71-9)$ & & & & & &
\end{tabular}

${ }^{a}$ Source: SciFinder database https://scifinder.cas.org/scifinder/view/scifinder/scifinderExplore.jsf

$\log D$ is logarithm of the distribution coefficient which is the ratio of the sum of concentrations of all forms of the compound (ionised and unionised) in octanol and water at a given $\mathrm{pH}$. 